\title{
Com espanto
}

\author{
Marta Sequeira \\ martasequeiracarneiro@gmail.com \\ Professora Auxiliar Convidada Da/UAL | Professora Auxiliar Convidada ISCTE-IUL \\ |lnvestigadora Integrada CIAUD-FAUL
}

Para citação: SEQUEIRA, Marta - Com espanto. Estudo Prévio 18 - Lisboa: CEACT/UAL Centro de Estudos de Arquitetura, Cidade e Território da Universidade Autónoma de Lisboa, 2020, p. 14-15. ISSN: 2182-4339 [Disponível em: www.estudoprevio.net]. DOI: https://doi.org/10.26619/2182-4339/18.1

Creative Commons, licence CC BY-4.0: https://creativecommons.org/licenses/by/4.0/

\section{Com espanto}

Espanto é um longo e inocente olhar sobre o objeto.

Theodor Adorno

Neste dossier são apresentados dois artigos: (1) "No encalço de Oscar" e (2) "A ténue linha entre arquitetura e escultura". Realizados por Flora del Debbio e Marco Rizzi e por Pasqualino Grosso e Carola Brandini, respetivamente, estes textos reflectem uma perspetiva sobre o que pode chegar a ser o trabalho de um aluno do curso de Mestrado Integrado em Arquitetura no âmbito de uma unidade curricular de Teoria e História da Arquitetura.

O primeiro artigo centra-se numa intrigante fotografia - tirada por Frank Scherschel para a famosa revista americana Life -, que retrata Oscar Niemeyer em Brasília, durante da sua construção. A partir da exposição de uma meticulosa análise desta imagem, vão sendo expostos os bastidores da sua composição, bem como desenhadas reveladoras conclusões sobre a vida e a obra de um dos mais importantes arquitectos do século XX. O segundo artigo, por sua vez, centra-se numa obra algo desconhecida, Sculpture Village, realizada por Frank Gehry com Anthony Caro em 1987. A partir da análise deste projeto torna-se finalmente possível chegar a uma série de conclusões fundamentadas sobre o papel da escultura na obra de um dos expoentes máximos da contemporaneidade. Em ambas as investigações, o objecto de estudo - bem seja uma fotografia de Frank Scherschel ou os vestígios que restam de 
Sculpture Village - não é mais que uma caixa de ressonância para observar, afinal e criticamente, a obra do seu autor. Em ambas as investigações, o recurso a fontes primárias - como desenhos, fotografias de maquetas, textos, publicações da época ou até entrevistas especialmente realizadas para este fim -, desempenham um papel primordial.

Numa época que nos programa para olhares breves, fugazes e utilitários, os autores destes dois artigos dedicam-se a analisar o material arquivístico de que dispõem - e que procuraram - com estranhamento (com espanto) e, por isso, com minúcia. Fizeram algo raro nos nossos dias, abrindo-se à revelação do documento, ao que ele nos oferece, e não ao que pretendemos ver consagrado. Ao contrário de muitos escritos que têm como base escritos que, apenas remotamente, têm como base os projectos, neste caso são os próprios documentos que vão dando pistas (hoje dispersos por diversas instituições, que vão da Fundação Oscar Niemeyer no Rio de Janeiro à Getty Foundation em Los Angeles). Os objectos de estudo são analisados a partir do modelo da crítica inferencial - reconstruindo analiticamente as suas causas e os seus fins, deduzidos a partir da relação estabelecida entre Niemeyer ou Gehry e as suas circunstâncias objetivas, ao mesmo tempo que iluminando aspetos que não eram evidentes até agora. Os seus autores partem, afinal, da observação dos fenómenos da realidade concreta para deles então conseguirem extrair, através da inferência, a lei universal que incorporam. A partir daí, torna-se possível chegar a uma série de conclusões que têm como base um olhar descomprometido relativamente aos objectos de estudo, chegando-se mesmo a refutar algumas falsas ideias claras. A arquitectura constitui assim, verdadeiramente, a validação última de qualquer conclusão, porque está genuinamente na sua origem. Estes artigos são, assim, absolutamente originais - não porque são diferentes, não porque são completamente novos, mas porque compreendem a origem do que se dispõem a analisar.

Da leitura destes artigos transparece que a investigação teórica está intimamente relacionada com o acto criativo porque corresponde sempre, em certa medida, a assumir um comprometimento com os seus actores, e em procurar fazer uma espécie de reconstituição hipotética das situações históricas. De facto, apesar do exercício da história e da teoria poder parecer, à primeira vista, uma mera passagem a limpo, pode ser ainda um exercício criativo, porque implica, em cada momento, observar, interpretar, fazer escolhas - recriar a realidade, no verdadeiro sentido do termo (fazêla de novo).

Os autores destes artigos não fizeram, simplesmente, um trabalho sobre História, ou um trabalho sobre Teoria, mas chegaram a fazer História e a fazer Teoria. E no âmbito de um curso de Mestrado Integrado em Arquitectura não se pode ambicionar menos que isto. Estes autores foram, afinal, treinados como potenciais investigadores em Teoria e História da Arquitectura, mas também, e principalmente, como potenciais Arquitectos. Transformaram-se, por momentos, em colaboradores próximos de Oscar Niemeyer e de Frank Gehry, mantendo, ao mesmo tempo, a consciência de serem eles próprios. 